ORIGINAL ARTICLE

\title{
Analysis of IMGSAC autism susceptibility loci: evidence for sex limited and parent of origin specific effects
}

\author{
J A Lamb, G Barnby, E Bonora, N Sykes, E Bacchelli, F Blasi, E Maestrini, J Broxholme, J Tzenova, \\ D Weeks, A J Bailey, A P Monaco, the International Molecular Genetic Study of Autism \\ Consortium (IMGSAC)
}

See end of article for authors' affiliations

Correspondence to: Dr A P Monaco, Wellcome Trust Centre for Human Genetics, University of Oxford, Roosevelt Drive, Oxford, OX3 7BN, UK; anthony.monaco@well.ox. ac.uk; A J Bailey, Section of Child and Adólescent Psychiatry, University Department of Psychiatry, Park Hospital for Children, Oxford, OX3 7LQ, UK; anthony.bailey@ psychiatry.ox.ac.uk

Received 26 July 2004 Revised

23 September 2004

Accepted

26 September 2004
A utism (OMIM \#209850) is a severe neurodevelopmental disorder which affects approximately 200 in 100000 individuals, although related disorders affect a further 400 in 100000 people. $^{1}$ Onset is before 3 years of age, and the core deficits, comprising qualitative impairments in reciprocal communication and social interaction, and repetitive and stereotyped behaviours and interests, persist throughout life. There is evidence for a complex genetic susceptibility to most cases of autism, and statistical modelling suggests the involvement of perhaps three or four loci, although up to 15 may be implicated..$^{23}$ Many groups have undertaken genomewide screens for autism susceptibility loci using affected sibling pairs (ASP), followed by a positional functional candidate gene approach (see Lamb et $a l^{4}$ and Folstein and Rosen-Sheidley ${ }^{5}$ for review). Encouragingly, there is convergent evidence for linkage for several chromosome regions. However, the identified genomic regions are large and, in the absence of replicated association findings, researchers have tried to minimise clinical and genetic heterogeneity to improve localisation of the linkage signals. ${ }^{6-9}$ Three quarters of individuals affected by autism are male, suggesting the involvement of sex specific factors in autism susceptibility. However, there is little evidence from genetic studies for involvement of genes on the $\mathrm{X}$ chromosome in the majority of individuals with autism. Linkage that is dependent on the sex of the affected individual has been reported previously in studies of other complex diseases including inflammatory bowel disease, hypertension, diabetes, and the personality trait neuroticism, ${ }^{10-13}$ therefore we reasoned that proband sex might be a useful index of heterogeneity in our sample. We have reported previously the results of a genomewide screen for autism susceptibility loci in 83 ASP, and follow up analysis in 152 ASP. ${ }^{14}{ }^{15}$ Here, we report linkage analysis in an expanded sample of 219 ASP at the principal loci on chromosomes 2, 7 , $9,10,16$, and 17. In addition, loci on chromosomes 3, 13, and 15 have been investigated further because of reports of linkage of autism and specific language impairment to chromosomes 3 and $13,{ }^{16-18}$ and linkage and an increased incidence of cytogenetic abnormalities of chromosome 15q11-q13 in autism ${ }^{19}$ (see Lamb et $a l^{4}$ for review). Analysis by proband sex and identity by descent (IBD) sharing partitioned into paternal and maternal components was carried out at the loci on chromosomes 2q,7q,9p, 15q, and $16 \mathrm{p}$.

\section{MATERIALS AND METHODS}

Family collection and phenotypic assessment

The identification of families and assessment methods used by the IMGSAC has been described in detail previously. ${ }^{14}{ }^{15} \mathrm{In}$ families passing an initial screen, parents were given the Autism Diagnostic Interview Revised (ADI-R) ${ }^{20}$ and the Vineland Adaptive Behaviour Scales. ${ }^{21}$ Potential cases, all $\geqslant 4$ years old, were also assessed using either the Autism Diagnostic Observation Schedule (ADOS) ${ }^{22}$ or ADOS Generic (ADOS-G). ${ }^{23}$ When possible, psychometric evaluation was also conducted using Raven's progressive matrices ${ }^{24}$ or the Mullen Scales of Early Learning, ${ }^{25}$ and the British Picture Vocabulary Scale ${ }^{26}$ or the Peabody Picture Vocabulary Test

Abbreviations: ADI-R, Autism Diagnostic Interview Revised; ADOS, Autism Diagnostic Observation Schedule; ADOS-G, Autism Diagnostic Observation Schedule Generic; ASP, affected sibling pairs; IBD, identity by descent 
III $^{27}$ or an appropriate translation; other tests were administered if clinically indicated.

Families were collected and genotyped in five successive stages, for a total of 420 affected individuals and 219 nonindependent affected sibling pairs from 207 families. The male:female ratio of these affected individuals is 3.94:1. The 219 ASP comprise 145 male-male ASP, 59 male-female ASP and 15 female-female ASP, with the male-female and female-female ASP combined to give a group of 74 nonmale ASP. There is no known overlap between these families and those ascertained by other research groups.

Physical examination was undertaken to exclude recognisable medical causes of autism. Blood samples were taken for DNA extraction when possible from all probands and available first degree relatives, and lymphoblastoid cell lines generated. Buccal swabs were taken when a blood sample could not be obtained (3.2\% of samples). Karyotypes were obtained on all affected individuals when possible, and Fragile $\mathrm{X}$ results obtained on one affected individual per family where possible. Karyotype abnormalities were excluded in at least one affected individual per family in $93 \%$ of families and in both affected individuals in $83 \%$ of families. Fragile $\mathrm{X}$ was excluded in at least one affected individual in $98 \%$ of families. The study has been reviewed by the relevant local ethics committees.

\section{Genomic DNA extraction and genotyping}

Genomic DNA extraction, amplification, and genotyping were performed as described previously according to standard protocols. ${ }^{14}{ }^{15}$ Genetic marker positions were taken from the deCODE genetics sex averaged map, ${ }^{28}$ and additional marker positions interpolated from their physical position on the UCSC genomic sequence browser. ${ }^{29}$ Informative microsatellite markers at a density of $\sim 5 \mathrm{cM}$ were chosen from the densely typed regions of linkage on chromosomes 2, 7, and 16 , as this map density has been shown to be most effective for linkage analysis. ${ }^{30}$ Discovery Manager (version 2.3; Genomica Corp.) and subsequently the LIMS Integrated Genotyping System database (http://www.well.ox.ac.uk/IGS) were used to store all genotypic and phenotypic data and to produce files for statistical analysis.

\section{Statistical analysis}

Prior to analysis, multi-marker haplotypes were constructed using GeneHunter (version 2.0) (11 $^{1}$ to check for excessive recombination events indicative of genotyping errors or marker mutation. Recombinant individuals were re-scored when necessary. In addition, Merlin software ${ }^{32}$ was run to identify possible genotyping errors, and flagged genotypes removed from subsequent analyses. Data was prepared for statistical analysis using Mega2. ${ }^{33}$

Estimated marker heterozygosity, effective sample size, and single point MLS scores were calculated using SPLINK. ${ }^{34}$ Multipoint lod scores were computed using ASPEX sib_phase under an additive model (no dominance variance), and paternal and maternal contributions evaluated using the sex_split option. ${ }^{35}$ Empirical significance levels for the sex limited effect on chromosomes 7, 9, 15, and 16 were determined by randomly permuting ASP sex and running ASPEX 10000 times while keeping the number of male and non-male ASP the same. Pedigree structures and all phenotypic and genotypic values were maintained.

To assess the support for the presence of two autism susceptibility loci on chromosome 7, joint analysis of two loci simultaneously was performed using TwoLoc, ${ }^{36}$ a nonparametric two locus linkage method that can be used to assess the support for linkage to a second putative susceptibility locus that is linked to an established susceptibility locus, by taking into account the interdependency between the two linked loci. TwoLoc calculates a two locus MLS for affected sibling pairs by specifying the joint two locus allele sharing probabilities as a function of the variance components and disease prevalence. The joint IBD sharing probabilities are maximised with respect to the genetic model specified. Analyses in TwoLoc were performed under two genetic models: a general two locus model, under which the joint IBD can vary freely within the valid ranges, and a single locus model under which the IBD probabilities are restricted. To obtain the joint two locus IBD sharing probabilities, TwoLoc uses family likelihood calculation output from Vitesse, ${ }^{37}$ which allows for sex specific recombination rates but is limited to eight markers. Therefore, we also used Merlin ${ }^{32}$ to calculate the joint two locus IBD probabilities using all markers on chromosome 7, but with sex averaged recombination rates only. Support for linkage to the second hypothetical disease locus in TwoLoc is calculated as the difference in MLS between a two locus and a single locus model.

\section{RESULTS}

Linkage analysis was carried out in 219 ASP at the principal loci on chromosomes 2, 7, 9, 10, 16, and 17 indicated by our previous results in 152 ASP. ${ }^{14}{ }^{15}$ In addition, loci on chromosomes 3, 13, and 15 were investigated based on published research. ${ }^{16} 1719$ The position, heterozygosity and effective sample size of the 396 markers used in these analyses are shown in the supplementary table online. Mean marker heterozygosity across the genome was 0.78 .

Multipoint linkage analysis using ASPEX generated MLS $>2$ on chromosomes 2q, 7q, and 9p (fig 1A), with MLS of 2.54 near D2S2314 on chromosome 2q, 2.31 near D7S530 on chromosome 7q, and 2.12 near D9S161 on chromosome 9p. The next highest MLS were 1.73 at D16S497 on chromosome $16 \mathrm{p}$, and 1.67 on chromosome $9 \mathrm{q}$ towards the telomere in the interval D9S158-D9S905. These data were supported by the single point SPLINK results (data not shown). There was no strong evidence for linkage on chromosomes 3, 13, or 15 $($ MLS $<1)$. The highest ASPEX multipoint MLS generated at the loci genotyped in the 219 ASP are presented in table 1.

Analysis according to the sex of the affected sibling pairs was carried out at the principal loci on chromosomes 2, 7, 9, and 16, and also on chromosome 15 because of the suggestion of genetic heterogeneity at this locus. ${ }^{15}$

The 219 ASP comprise 145 male, 59 male-female, and 15 female-female pairs. Because the subset of female pairs was considered too small to be analysed independently, malefemale and female-female pairs were combined to give a group of 74 non-male pairs. Analysis of the 145 male pairs generated MLS of 2.55 and 2.48 on chromosomes 7 and 16 respectively (fig 1B; table 1 ). No linkage to these regions was observed in the 74 non-male ASP (MLS $=0.12$ and 0.00 on chromosomes 7 and 16). Conversely, linkage to chromosome $15 \mathrm{q}$ was attributable to the non-male ASP (MLS $=2.62 \mathrm{v}$ 0.00 , for the non-male and male ASP respectively). On chromosomes 2 and 9, all ASP contributed to linkage. Empirical significance levels were determined by permutation (see methods), suggesting that this apparent sex limited effect on chromosomes $15(\mathrm{p}=0.0011)$ and $16(\mathrm{p}=0.026)$ is significant, whereas on chromosome 7 this effect failed to reach significance $(\mathrm{p}=0.075)$.

Paternal and maternal contributions to the linkage on chromosomes 2, 7, 9, 15, and 16 were evaluated using ASPEX sex_split (Fig 2). On chromosomes 2, 15, and 16, parent of origin linkage modelling showed IBD sharing from both parents at essentially the same position. On chromosome 7, two distinct regions of paternal and maternal IBD sharing were identified, with paternal MLS of 1.46 between markers D7S477 and D7S2453, and maternal MLS of 1.83 between 


\begin{tabular}{|c|c|c|c|c|c|c|c|}
\hline $\begin{array}{l}\text { Chrom. } \\
\text { no }\end{array}$ & Marker & Position* & $\begin{array}{l}\text { All } \\
(219) t\end{array}$ & $\begin{array}{l}\text { Male } \\
\text { (145) }\end{array}$ & $\begin{array}{l}\text { Non-male } \\
\text { (74) }\end{array}$ & Patł & Mat \\
\hline 2 & D2S2314-D2S2310 & $177.9-181.4$ & 2.54 & 1.25 & 1.39 & 1.40 & 1.35 \\
\hline 3 & D3S1297 & 10 & 0.65 & ND & ND & ND & ND \\
\hline \multirow[t]{3}{*}{7} & D7S477-D7S3453 & $113.1-118.1$ & & & & 1.46 & 0.53 \\
\hline & D7S480-D7S530 & $126.9-133.2$ & & $\begin{array}{l}2.55 \\
(p=0.075)\end{array}$ & 0.12 & & \\
\hline & D7S530-D7S640 & $133.2-141.2$ & 2.31 & & & 0.28 & 1.83 \\
\hline \multirow[t]{5}{*}{9} & D9S157 & 25.1 & & 0.30 & 1.89 & & \\
\hline & D9S157-D9S171 & $25.1-34.4$ & & & & 0.02 & 1.99 \\
\hline & D9S171-D9S161 & $34.4-40.4$ & 2.12 & & & & \\
\hline & D9S161 & 40.4 & & 1.92 & 0.20 & & \\
\hline & D9S158-D9S905 & $151.2-157.6$ & 1.67 & & & & \\
\hline 10 & DIOS189 & 24 & 1.15 & ND & ND & ND & ND \\
\hline \multirow[t]{3}{*}{15} & $\begin{array}{l}\text { D13S158-D13S173 } \\
\text { D15S129-CYP19 }\end{array}$ & $\begin{array}{l}92.7-103.1 \\
46.6-53.8\end{array}$ & 0.53 & ND & ND & $\begin{array}{l}\text { ND } \\
1.07\end{array}$ & $\begin{array}{l}\mathrm{ND} \\
0.90\end{array}$ \\
\hline & CYP19-D15S117 & $53.8-60.6$ & 0.89 & & & & \\
\hline & D15S117-D15S125 & $60.6-72.9$ & & 0.00 & $\begin{array}{l}2.62 \\
(p=0.0011)\end{array}$ & 0.68 & 1.59 \\
\hline \multirow[t]{3}{*}{16} & D16S407-D16S497 & $32.8-35.9$ & & $\begin{array}{l}2.48 \\
(p=0.026)\end{array}$ & 0.00 & 1.10 & \\
\hline & D16S497 & 35.9 & 1.73 & & & & \\
\hline & $\mathrm{D} 16 \mathrm{~S} 3102$ & 37.2 & & & & & 1.97 \\
\hline 17 & D17S513 & 10 & 1.13 & ND & ND & ND & ND \\
\hline $\begin{array}{l}\text { The max } \\
\text { modellin } \\
\text { MLS diffe } \\
\text { Merlin } \\
\text { of non-in } \\
\text { †For chr } \\
\text { respectiv }\end{array}$ & $\begin{array}{l}\text { imum multipoint MLS at } \\
g \text { are also shown for ch } \\
\text { ers between subgroups, } \\
(0.27 \%) \text {. }{ }^{*} \text { Estimated sex } \\
\text { dependent ASP analys } \\
\text { omosomes } 15 \text { and } 16, p \\
\text { ely. Chrom, chromoson }\end{array}$ & $\begin{array}{l}\text { ned when analys } \\
\text { nosomes } 2,7,9 \\
\text { I positions are sh } \\
\text { eraged position } \\
\text { Non-male ASP } \\
\text { ernal and matern } \\
\text { pat, paternal; } m\end{array}$ & $\begin{array}{l}\text { lusing af } \\
5 \text {, and } 16 \\
\text { wn. MLS } \\
\text { m pter in } \\
\text { nstitutes } \\
\text { MLS are } \\
\text {, matern }\end{array}$ & $\begin{array}{l}\text { fected sibling } \\
\text { 6. Note: whe } \\
\text { are shown a } \\
\text { CM. †Numb } \\
\text { male-female } \\
\text { shown for the } \\
\text { al; ND, not d }\end{array}$ & $\begin{array}{l}\text { ir sex and pare } \\
\text { he position of } m \\
\text { removal of err } \\
\text { in parentheses i } \\
\text { d female-femal } \\
\text { bgroup of non-r } \\
\text { rmined. }\end{array}$ & $\begin{array}{l}\text { nt of oric } \\
\text { aximum } \\
\text { rs ident } \\
\text { ndicate t } \\
\text { ASP co } \\
\text { nale and }\end{array}$ & $\begin{array}{l}\text { in linkage } \\
\text { multipoin } \\
\text { ied by } \\
\text { e number } \\
\text { nbined. } \\
\text { male ASP }\end{array}$ \\
\hline
\end{tabular}

markers D7S530 and D7S640 20 cM distally. The corresponding maternal and paternal MLS at these loci were 0.53 and 0.28 respectively. This effect was more apparent in the subset of male ASP (data not shown). On chromosome 9p, IBD sharing appeared to be largely maternally derived; maternal MLS $=1.99$ at $\sim 30 \mathrm{cM}$ (paternal MLS $=0.02$ ).

In order to assess support for the presence of two autism susceptibility loci on chromosome 7 , data was analysed in a maximum likelihood framework using TwoLoc. ${ }^{36}$ Analysis in Twoloc using all chromosome 7 markers and sex averaged recombination rates generated a peak MLS of 3.34 under the two locus general model at the intercept between marker D7S477 (locus 1, 111 cM) and the interval D7S530-D7S640 (locus 2, $134 \mathrm{cM}$ ) (fig 3). The MLS generated under the single locus model were 1.94 at D7S477 and 2.51 in the interval D7S530-D7S640 (133 cM). Linkage support for the presence of a secondary locus at $111 \mathrm{cM}$, independent of the locus at $134 \mathrm{cM}$, can be calculated as the difference $(0.83)$ between a two locus and a single locus MLS. ${ }^{36}$ The data were also analysed using sex specific recombination fractions obtained from the deCODE genetic map ${ }^{28}$ for more accurate resolution. This analysis was restricted to a subset of eight markers at the peak and resulted in an MLS of 3.31 under the two locus general model, and MLS of 2.13 and 2.31 at locus 1 and locus 2 respectively under the single locus model.

\section{DISCUSSION}

The addition of further ASP and analysis of existing data continues to support the existence of loci influencing autism susceptibility in the IMGSAC sample, with the loci on chromosomes 2 and 7 showing suggestive evidence for linkage. ${ }^{38}$ Nevertheless, the addition of further families has reduced the multipoint MLS on chromosomes 2, 10, 16, and 17 compared with previously reported results. ${ }^{15}$ The MLS on chromosome 9 has increased, and the maximum multipoint MLS on chromosome 7 is essentially unchanged, although the peak of linkage has moved $\sim 23 \mathrm{cM}$ distally. Previous studies have demonstrated a large degree of variation in linkage location estimates in studies of complex disease with modest power. ${ }^{39}$

The high ratio of males with autism indicates the possible involvement of sex specific factors in the development of the disorder, and a possible basis for genetic heterogeneity. A number of hypotheses have been posited to account for the higher incidence of autism in males, including $X$ linked inheritance. However, this is not consistently supported by genetic linkage studies, ${ }^{3} 1404$ and evidence suggests a higher incidence of the broader autistic phenotype in fathers than in mothers. ${ }^{42}$ There is little evidence for the involvement of the $\mathrm{X}$ chromosome in the majority of cases. Analysis according to the sex of ASP suggests that linkage to chromosome 16 is limited to male affected sibling pairs in the IMGSAC sample, a finding supported by empirical significance thresholds determined by simulation. The same trend is observed on chromosome 7, but narrowly fails to reach significance. Linkage to chromosome $15 \mathrm{q}$ in this sample is limited to the non-male ASP. A relatively high incidence of cytogenetic abnormalities of chromosome 15, in particular maternally inherited duplications of 15q11-q13, the most commonly documented chromosomal abnormalities leading to an autistic phenotype, ${ }^{43}{ }^{44}$ suggest a possible cause of genetic heterogeneity at this locus. However, the linkage reported here in the non-male ASP is to 15q21.3-q22.31, at least $25 \mathrm{Mb}$ distal to $15 \mathrm{ql} 1-\mathrm{q} 13$, so it is unlikely that this linkage represents the same locus. It is not yet clear whether the cytogenetic abnormalities of 15q11-q13 are at an increased frequency in autistic females. These results support the usefulness of linkage analysis by affected sibling pair sex, and suggest that this approach may be useful for other neurodevelopmental disorders in which a similar sex bias is observed.

Evaluation of parent of origin contributions at these loci lends support to the hypothesis that there may be two discrete loci underlying linkage of autism to chromosome 7 , with possible parent of origin specific effects and the role of an imprinted gene/s. However, the results of two locus analysis using TwoLoc suggest that the majority of evidence 
A

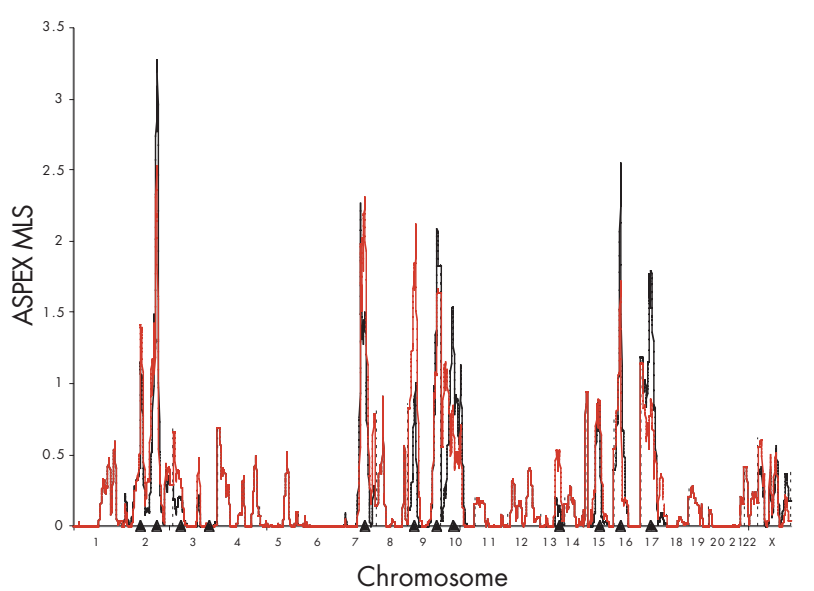

B
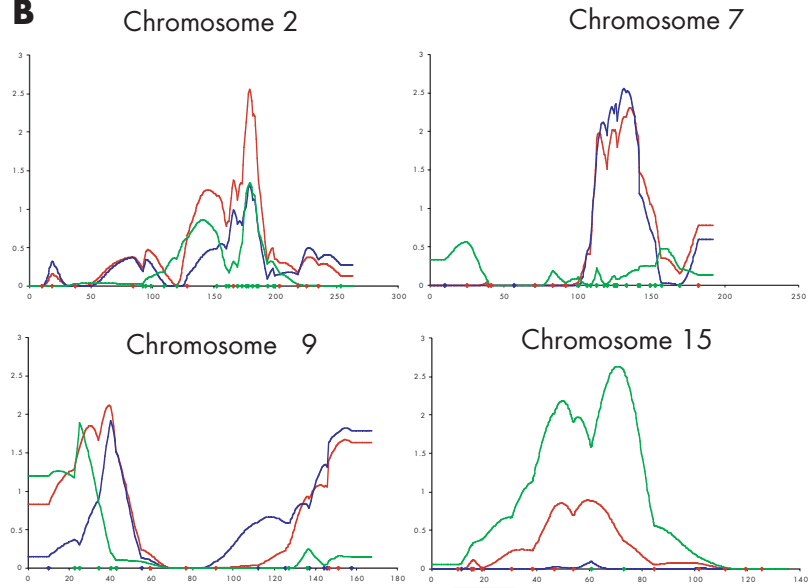

Chromosome 16

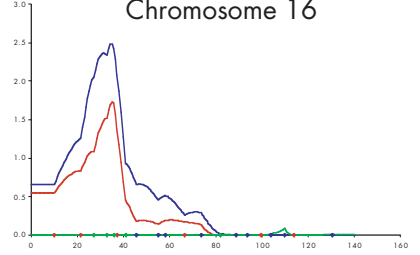

Figure 1 Multipoint linkage results generated by ASPEX under an additive model with no dominance variance. The results are presented after removal of possible errors identified using Merlin. ${ }^{32}$ (A) Multipoint map across all chromosomes from pter to gter (red line). Loci typed in the whole sample of 219 ASP are indicated by triangles on the $x$ axis. The results of analysis after stage 4 (152 ASP) are shown for comparison (black line). The results presented here differ slightly from those reported previously for stage $4^{15}$ due to refinement of the genetic map, and differences in the method of error detection. (B) Linkage analysis of chromosomes 2,7, 9, 15, and 16 according to ASP sex. Red, total sample of 219 ASP; blue, 145 male ASP; green, 74 non-male ASP; $x$ axis, position from pter in $\mathrm{CM}$ from the deCODE map. The positions of markers are represented by diamonds on the $x$ axis with the effective sample size (ESS) indicated by: blue, ESS $<50$; red, ESS 50-100; green, ESS $>100$. The black line below the chromosome 15 figure indicates the region $15 q 11-q 13$.

for linkage comes from locus 2 (D7S530-D7S640), and the additional support for linkage at locus 1 (D7S477), assuming that locus 2 is linked, is MLS $=0.83$, indicating that these results should be interpreted with caution.

The involvement of parental sex in autism has previously been indicated by the maternally inherited duplications of 15q11-q13, and several developmental disorders have been
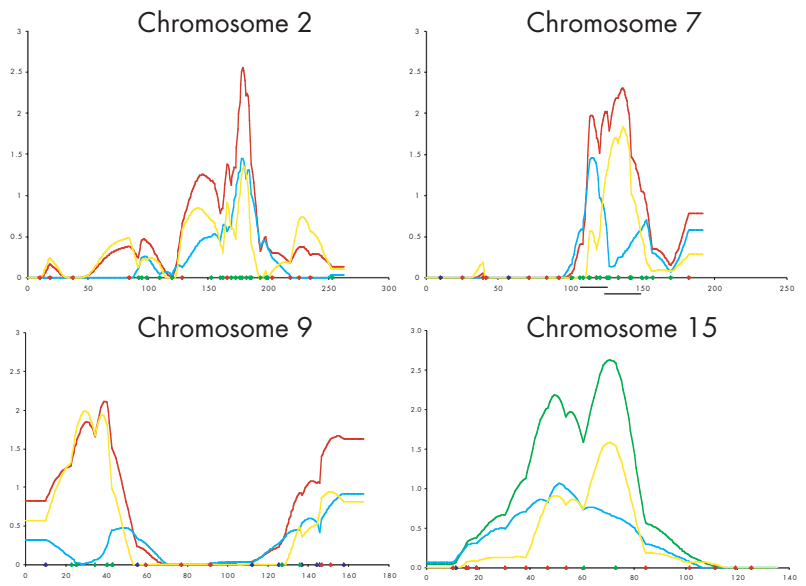

Chromosome 16

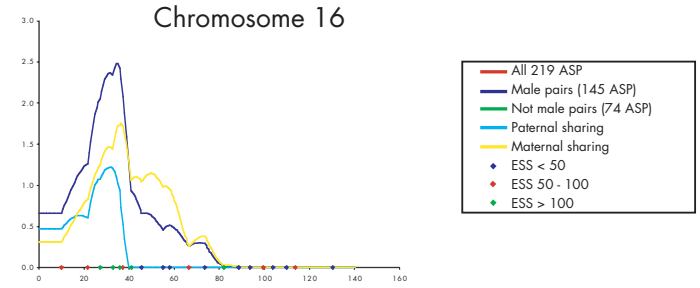

Figure 2 Parent of origin linkage modelling on chromosomes 2, 7, 9 15 and 16 generated using ASPEX sex_split: chromosomes 2, 7, and 9; multipoint linkage in total sample of 219 ASP; chromosome 15;

multipoint linkage in 74 non-male ASP, and chromosome 16; multipoint linkage in 145 male ASP. Red, total sample of 219 ASP; blue, 145 male ASP; green, 74 non-male ASP; turquoise, paternal identity by descent (IBD) sharing; yellow, maternal IBD sharing. The black lines below the chromosome 7 figure show the one-lod support interval for regions of paternal and maternal IBD sharing; $x$ axis, position from pter in $\mathrm{CM}$ using the deCODE sex averaged map. The positions of markers are represented by diamonds on the $x$ axis with the effective sample size (ESS) in the total sample indicated by: blue, ESS $<50$; red, ESS 50-100; green, ESS $>100$.

associated with imprinting defects, including Angelman, Beckwith-Wiedemann, and Prader-Willi syndromes. ${ }^{45-47}$ Prader-Willi and Angelman syndromes result from loss of expression at oppositely imprinted neighbouring genomic loci in the 15q11-q13 region. This clustering of differentially imprinted genes has been reported for a number of other genomic loci. ${ }^{48} 49$ The association of aberrant imprinting with several human cancers is interesting, ${ }^{50}$ given the mapping of

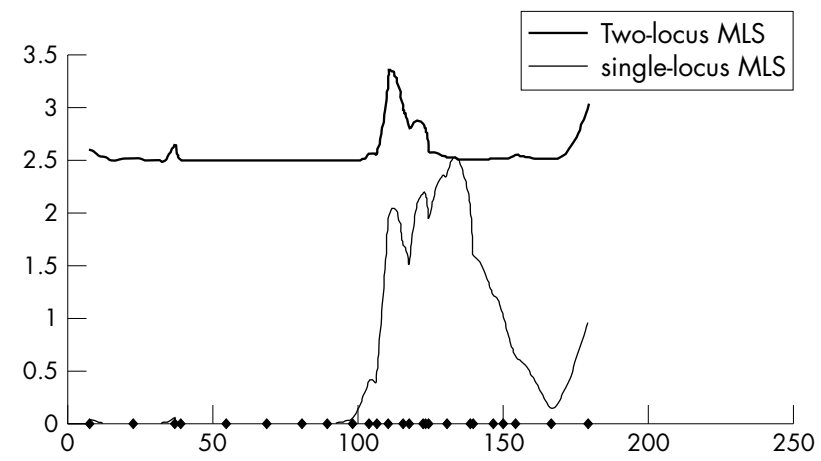

Figure 3 Increase in the MLS for a two locus model, assuming a primary susceptibility locus at $134 \mathrm{cM}$, versus the single locus MLS results. Results were obtained across all markers on chromosome 7 using TwoLoc with sex averaged recombination rates from the deCODE sex averaged map in the total sample of 219 ASP. Thin line, single locus MLS; thick line, two locus MLS. The positions of markers are represented by diamonds on the $\mathrm{x}$ axis. 
loci for acute myeloid leukaemia and acute lymphoblastic leukaemia to our regions of linkage on chromosomes 7 and 9 respectively.

The identification of possible sex limited and parent of origin specific effects on chromosomes 7, 9, 15, and 16 should facilitate a more focused approach to candidate gene screening. The human reelin gene maps to $7 q 22$, within the region of paternal linkage, and has been suggested as a candidate for autism susceptibility (see Bonora et $a^{51}$ for review). Interestingly, a progressive Purkinje cell loss has been reported in the cerebellum of male heterozygous reeler mice, while the females are spared. ${ }^{52}$ However, screening the coding sequence of this gene for autism susceptibility variants in the IMGSAC sample did not reveal any putative aetiological variants with a high enough frequency to explain the strength of the linkage findings. ${ }^{51}$ A number of imprinted genes have already been identified on chromosome 7 , including several genes within the region of maternal linkage. ${ }^{48}{ }^{53}$ Future studies will determine if other genes/ transcripts in this region are preferentially expressed from one parental allele.

These results suggest the usefulness of genomewide analysis by affected sibling pair sex and evaluation of parent of origin effects, although future studies are necessary to determine if these results can be replicated. The suggestion of narrower confidence intervals for the linkage signal on chromosome 7 demarcates a region suitable for high resolution association mapping. However, the possible involvement of epigenetic rather than genetic variation may be an explanation for the lack of causative variants so far identified in candidate genes in these regions.

\section{ACKNOWLEDGEMENTS}

This work would not have been possible without the co-operation of all the families and the many referring professionals. This work has been funded by the UK Medical Research Council, The Wellcome Trust, BIOMED 2 (CT-97-2759), EC Fifth Framework (QLG2-CT1999-0094), Telethon-Italy (GGP030227), Fondazione Cassa di Risparmio di Bologna, the Janus Korczak Foundation, Deutsche Forschungsgemeinschaft, Fondation France Télécom, Conseil Régional Midi-Pyrénées, Danish Medical Research Council, Sofiefonden, the Beatrice Surovell Haskells Fond for Child Mental Health Research of Copenhagen, the Danish Natural Science Research Council (9802210), and the National Institutes of Health (U19 HD35482, MO1 RR06022, K05 MH01196, K02 MH01389). A J Bailey is the Cheryl and Reece Scott Professor of Psychiatry. A P Monaco is a Wellcome Trust Principal Research Fellow.

\section{Authors' affiliations}

J A Lamb, G Barnby, E Bonora*, N Sykes, J Broxholme, J Tzenova, A P Monaco, Wellcome Trust Centre for Human Genetics, University of Oxford, Oxford, UK

E Bacchelli, F Blasi, E Maestrini, University of Bologna, Dipartimento di Biologia Evoluzionistica Sperimentale and Laboratorio di Genetica Medica-Policlinico S. Orsola, Bologna, Italy

J Tzenova, Department of Cardiovascular Medicine, University of Oxford, Oxford, UK

D Weeks, Department of Human Genetics, University of Pittsburgh, Pittsburgh, USA

A J Bailey, Section of Child and Adolescent Psychiatry, University Department of Psychiatry, Park Hospital for Children, Oxford, UK

*Present address: Unità di Genetica Medica, Policlinico S. Orsola, Bologna, Italy

\section{Competing interests: none declared}

The IMGSAC website is http://www.well.ox.ac.uk/ maestrin/iat.html. Members of the IMGSAC are as follows. UK: Section of Child and Adolescent Psychiatry, University Department of Psychiatry, Park Hospital for Children, Oxford: N Mathews, J Parr, S Wallace and A Bailey; Wellcome Trust Centre for Human Genetics, University of Oxford: G Barnby, E Bonora, J Lamb, A Marlow, N Sykes and A Monaco; Social, Genetic \& Development Research Centre, Institute of
Psychiatry, London: P Bolton and M Rutter; Newcomen Centre, Guy's Hospital, London: G Baird; South East Thames Regional Genetics Centre, Division of Medical and Molecular Genetics, Guy's Hospital, London: S Abbs, Z Docherty, C Ogilvie and P Warburton; School of Clinical Medical Sciences, University of Newcastle: T Berney, A Le Couteur and $\mathrm{H}$ McConachie; Developmental Psychiatry Section, University of Cambridge Clinical School: P de Vries and E Weisblatt; Academic Department of Child Psychiatry, University of Manchester: C Aldred, J-A Wilkinson and J Green; School of Epidemiology \& Health Science, University of Manchester: A Pickles; European Collection of Cell Cultures, Health Protection Agency, Porton Down: P Bracegirdle, R Packer and B Bolton. Italy: University of Bologna, Dipartimento di Biologia Evoluzionistica Sperimentale, Bologna: E Bacchelli, F Blasi, S Carone and E Maestrini. The Netherlands: AZU, Department of Child and Adolescent Psychiatry, Utrecht: Maretha De Jonge, C Kemner, M Scherpenisse, $\mathrm{K}$ Steggehuis and $\mathrm{H}$ Van Engeland; Department of Child Psychiatry, Utrecht: I den Hartog. Germany: Deutsches Krebsforschungszentrum, Molecular Genome Analysis, Heidelberg: S M Klauck, B Felder, C Schuster and A Poustka; JW GoetheUniversität, Department of Child and Adolescent Psychiatry, Frankfurt: S Bölte, S Feineis-Matthews, N Uhlig, D Rühl, G Schmötzer and F Poustka. France: Hôpital la Grave, Toulouse: E Fombonne, J FremolleKruck, C Mantoulan, K Wittemeyer and B Rogé. Denmark: Centre for Autisme, Bagsvaerd: E Ulsted Sorensen, B Viskum, R Cotterill, K Brondum-Nielsen, G Eriksen, D Haracopos, $T$ Isager and L Pedersen. Greece: Agia Sophia Children's Hospital, Athens: K Papanikolaou and J Tsiantis. USA: Departments of Human Genetics and Biostatistics, University of Pittsburgh Graduate School of Public Health: D Weeks; Department of Psychiatry, University of Chicago: J Salt, S Guter, B Leventhal and E Cook; UCLA Center for Neurobehavioural Genetics, Los Angeles: S Nelson and S Smalley; UCLA Psychiatric Institute, Child Psychiatry Division: J Levitt; University of Michigan Autism and Communicative Disorders Center, Ann Arbor: C Corsello and C Lord; Yale University, New Haven: J Bregman, A Klin, $\mathrm{K}$ Koenig, R Oti and F Volkmar.

\section{REFERENCES}

1 Chakrabarti S, Fombonne E. Pervasive developmental disorders in preschool children. Jama 2001;285:3093-9.

2 Pickles A, Bolton P, Macdonald H, Bailey A, Le Couteur A, Sim CH, Rutter M. Latent-class analysis of recurrence risks for complex phenotypes with selection and measurement error: a twin and family history study of autism. Am J Hum Genet 1995;57:717-26.

3 Risch N, Spiker D, Lotspeich L, Nouri N, Hinds D, Hallmayer J, Kalaydjieva L, McCague P, Dimiceli S, Pitts T, Nguyen L, Yang J, Harper C, Thorpe D, Vermeer S, Young H, Hebert J, Lin A, Ferguson J, Chiotti C, Wiese-Slater S, Rogers T, Salmon B, Nicholas P, Myers RM. A genomic screen of autism: evidence for a multilocus etiology. Am J Hum Genet 1999;65:493-507.

4 Lamb JA, Parr JR, Bailey AJ, Monaco AP. Autism: in search of susceptibility genes. Neuromolecular Med 2002;2:11-28.

5 Folstein SE, Rosen-Sheidley B. Genetics of autism: complex aetiology for a heterogeneous disorder. Nat Rev Genet 2001;2:943-55.

6 Bradford Y, Haines J, Hutcheson H, Gardiner M, Braun T, Sheffield V, Cassavant T, Huang W, Wang K, Vieland V, Folstein S, Santangelo S, Piven J Incorporating language phenotypes strengthens evidence of linkage to autism. Am $J$ Med Genet 2001;105:539-47.

7 Buxbaum JD, Silverman JM, Smith CJ, Kilifarski M, Reichert J, Hollander E, Lawlor BA, Fitzgerald M, Greenberg DA, Davis KL. Evidence for a susceptibility gene for autism on chromosome 2 and for genetic heterogeneity. Am J Hum Genet 2001;68:1514-20.

8 Shao Y, Raiford KL, Wolpert CM, Cope HA, Ravan SA, Ashley-Koch AA Abramson RK, Wright HH, DeLong RG, Gilbert JR, Cuccaro ML, PericakVance MA. Phenotypic homogeneity provides increased support for linkage on chromosome 2 in autistic disorder. Am J Hum Genet 2002;70:1058-61

9 Buxbaum JD, Silverman J, Keddache M, Smith CJ, Hollander E, Ramoz N, Reichert JG. Linkage analysis for autism in a subset families with obsessivecompulsive behaviors: evidence for an autism susceptibility gene on chromosome 1 and further support for susceptibility genes on chromosome 6 and 19. Mol Psychiatry 2004;9:144-50

10 Fisher SA, Hampe J, Macpherson AJ, Forbes A, Lennard-Jones JE, Schreiber S, Curran ME, Mathew CG, Lewis CM. Sex stratification of an inflammatory bowel disease genome search shows male-specific linkage to the HLA region of chromosome 6. Eur J Hum Genet 2002;10:259-65.

11 O'Donnell CJ, Lindpaintner K, Larson MG, Rao VS, Ordovas JM, Schaefer EJ, Myers RH, Le Evidence for association and genetic linkage of the angiotensinconverting enzyme locus with hypertension and blood pressure in men but not women in the Framingham Heart Study. Circulation 1998;97:1766-72.

12 Kristiansen OP, Nolsoe RL, Larsen L. Association of a functional 17betaestradiol sensitive IL6-174G/C promoter polymorphism with early-onset type 1 diabetes in females. Hum Mol Genet 2003;12:1101-10.

13 Fullerton J, Cubin M, Tiwari H, Wang C, Bomhra A, Davidson S, Miller S, Fairburn C, Goodwin G, Neale MC, Fiddy S, Mott R, Allison DB, Flint J. Linkage analysis of extremely discordant and concordant sibling pairs 
identifies quantitative-trait loci that influence variation in the human personality trait neuroticism. Am J Hum Genet 2003;72:879-90.

14 IMGSAC. A full genome screen for autism with evidence for linkage to a region on chromosome 7q. Hum Mol Genet 1998;7:571-8.

15 IMGSAC. A genomewide screen for autism: strong evidence for linkage to chromosomes 2q, 7q, and 16p. Am J Hum Genet 2001;69:570-81

16 Bartlett CW, Flax JF, Logue MW, Vieland VJ, Bassett AS, Tallal P, Brzustowicz LM. A major susceptibility locus for specific language impairment is located on 13q21. Am J Hum Genet 2002;71:45-55

17 Auranen M, Vanhala R, Varilo T, Ayers K, Kempas E, Ylisaukko-Oja T, Sinsheimer JS, Peltonen L, Jarvela I. A genomewide screen for autismspectrum disorders: evidence for a major susceptibility locus on chromosome 3q25-27. Am J Hum Genet 2002;71:777-90.

18 S Shao Y, Wolpert CM, Raiford KL, Menold MM, Donnelly SL, Ravan SA Bass MP, McClain C, von Wendt L, Vance JM, Abramson RH, Wright $\mathrm{HH}$, Ashley-Koch A, Gilbert JR, DeLong RG, Cuccaro ML, Pericak-Vance MA. Genomic screen and follow-up analysis for autistic disorder. Am J Med Genet 2002; 114:99-105

19 Shao Y, Cuccaro ML, Hauser ER, Raiford KL, Menold MM, Wolpert CM, Ravan SA, Elston L, Decena K, Donnelly SL, Abramson RK, Wright HH, DeLong GR, Gilbert JR, Pericak-Vance MA. Fine mapping of autistic disorder to chromosome 15q11-q13 by use of phenotypic subtypes. Am J Hum Genet 2003;72:539-48

20 Lord C, Rutter M, Le Couteur A. Autism Diagnostic Interview-Revised: a revised version of a diagnostic interview for caregivers of individuals with possible pervasive developmental disorders. J Autism Dev Disord 1994;24:659-85.

21 Sparrow S, Balla D, Cicchetti D. Vineland adaptive behaviour scales. Minnesota: American Guidance Service, 1984.

22 Lord C, Rutter M, Goode S, Heemsbergen J, Jordan H, Mawhood L, Schopler E. Autism diagnostic observation schedule: a standardized observation of communicative and social behavior. J Autism Dev Disord 1989; 19:185-212.

23 Lord C, Risi S, Lambrecht L, Cook EH Jr, Leventhal BL, DiLavore PC, Pickles A, Rutter $M$. The autism diagnostic observation schedule-generic: a standard measure of social and communication deficits associated with the spectrum of autism. J Autism Dev Disord 2000;30:205-23.

24 Raven J. Standard progressive matrices. Victoria: Australian Council for Educational Research, 1989

25 Mullen EM. Mullen's scales of early learning. Minnesota: American Guidance Service, 1995.

26 Dunn LM, Dunn LM, Whetton C, Pintilie D. British picture vocabulary scale. Windsor: NFER-Nelson, 1982

27 Dunn LM, Dunn LM. Peabody picture vocabulary test, 3th ed. Minnesota: American Guidance Service, 1997

28 Kong A, Gudbjartsson DF, Sainz J, Jonsdottir GM, Gudjonsson SA, Richardsson B, Sigurdardottir S, Barnard J, Hallbeck B, Masson G, Shlien A, Palsson ST, Frigge ML, Thorgeirsson TE, Gulcher JR, Stefansson K A highresolution recombination map of the human genome. Nat Genet 2002;31:241-7

29 UCSC Genome Bioinformatics. Available at: http://genome.ucsc.edu/

30 Feakes R, Sawcer S, Chataway J, Coraddu F, Broadley S, Gray J, Jones HB Clayton D, Goodfellow PN, Compston A. Exploring the dense mapping of a region of potential linkage in complex disease: an example in multiple sclerosis. Genet Epidemiol 1999;17:51-63.

31 Kruglyak L, Daly MJ, Reeve-Daly MP, Lander ES. Parametric and nonparametric linkage analysis: a unified multipoint approach. Am J Hum Genet 1996:58:1347-63.

32 Abecasis GR, Cardon LR, Cookson WO, Sham PC, Cherny SS. Merlin--rapid analysis of dense genetic maps using sparse gene flow trees. Nat Genet 2002;30:97-101.

33 Mukhopadhyay N, Almasy L, Schroeder M, Mulvihill WP, Weeks DE. Mega2, a data-handling program for facilitating genetic linkage and association analyses. Am J Hum Genet 1999;65:A436.
34 Holmans P. Asymptotic properties of affected-sib-pair linkage analysis. Am J Hum Genet 1993;52:362-74.

35 Hinds D, Risch N. The ASPEX package: affected sib-pair mapping, 1996 Available at: ftp://lahmed.stanford.edu/pub/aspex.

36 Farrall M. Affected sibpair linkage tests for multiple linked susceptibility genes. Genet Epidemiol 1997; 14:103-15.

37 O'Connell JR, Weeks DE. The VITESSE algorithm for rapid exact multilocus linkage analysis via genotype set-recoding and fuzzy inheritance. Nat Genet $1995 ; 11: 402-8$

38 Lander E, Kruglyak L. Genetic dissection of complex traits: guidelines for interpreting and reporting linkage results. Nat Genet 1995;11:241-7.

39 Roberts SB, MacLean CJ, Neale MC, Eaves U, Kendler KS. Replication of linkage studies of complex traits: an examination of variation in location estimates. Am J Hum Genet 1999;65:876-84.

40 Hallmayer J, Hebert JM, Spiker D, Lotspeich L, McMahon WM, Petersen PB, Nicholas P, Pingree C, Lin AA, Cavalli-Sforza LL, Risch N, Ciaranello RD. Autism and the X chromosome. Multipoint sib-pair analysis. Arch Gen Psychiatry 1996;53:985-9.

41 Philippe A, Martinez M, Guilloud-Bataille M, Gillberg C, Rastam M, Sponheim E, Coleman M, Zappella M, Aschaver H, Van Maldergem L, Penet C, Feingold J, Brice A, Leboyer M, van Malldergerme L. Genome-wide scan for autism susceptibility genes. Paris Autism Research International Sibpair Study. Hum Mol Genet 1999;8:805-12 (published erratum appears in Hum Mol Genet 1999;8:1353).

42 Pickles A, Starr E, Kazak S, Bolton P, Papanikolaou K, Bailey A, Goodman R, Rutter $M$. Variable expression of the autism broader phenotype: findings from extended pedigrees. J Child Psychol Psychiatry 2000;41:491-502.

43 Repetto GM, White LM, Bader PJ, Johnson D, Knoll JH. Interstitial duplications of chromosome region $15 q 1 \mathrm{lq} 13$ : clinical and molecular characterization. Am J Med Genet 1998;79:82-9.

44 Schroer RJ, Phelan MC, Michaelis RC, Crawford EC, Skinner SA, Cuccaro M, Simensen RJ, Bishop J, Skinner C, Fender D, Stevenson RE. Autism and maternally derived aberrations of chromosome 15q. Am J Med Genet 1998;76:327-36

45 Clayton-Smith J, Laan L. Angelman syndrome: a review of the clinical and genetic aspects. J Med Genet 2003:40:87-95.

46 Mann MR, Bartolomei MS. Towards a molecular understanding of PraderWilli and Angelman syndromes. Hum Mol Genet 1999;8:1867-73.

47 Weksberg R, Smith AC, Squire J, Sadowski P. Beckwith-Wiedemann syndrome demonstrates a role for epigenetic control of normal development. Hum Mol Genet 2003;12 Spec No 1:R61-8

48 Schroer RJ, Phelan MC, Michaelis RC, Crawford EC, Skinner SA, Cuccaro M, Simensen RJ, Bishop J, Skinner C, Fender D, Stevenson RE. A new imprinted cluster on the human chromosome 7q21-q31, identified by human-mouse monochromosomal hybrids. Genomics 2003;81:556-9.

49 Morison IM, Reeve AE. A catalogue of imprinted genes and parent-of-origin effects in humans and animals. Hum Mol Genet 1998:7:1599-609.

50 Murphy SK, Jirtle RL. Imprinting evolution and the price of silence. Bioessays 2003;25:577-88.

51 Bonora E, Beyer KS, Lamb JA, Parr JR, Klauck SM, Benner A, Paolucci M, Abbott A, Ragoussis I, Poustka A, Bailey AJ, Monaco AP; International Molecular Genetic Study of Autism (IMGSAC Analysis of reelin as a candidate gene for autism. Mol Psychiatry 2003;8:885-92.

52 Hadj-Sahraoui N, Frederic F, Delhaye-Bouchaud N, Mariani J. Gender effect on Purkinje cell loss in the cerebellum of the heterozygous reeler mouse. J Neurogenet 1996:11:45-58.

53 Yamada T, Mitsuya K, Kayashima T, Yamasaki K, Ohta T, Yoshiura K, Matsumoto N, Yamada H, Minakami H, Oshimura M, Niikawa N Kishino T. Imprinting analysis of 10 genes and/or transcripts in a $1.5-\mathrm{Mb}$ MEST-flanking region at human chromosome 7q32. Genomics 2004;83:402-12 